\title{
Prostate Cancer TNM Finding v6
}

National Cancer Institute

\section{Source}

National Cancer Institute. Prostate Cancer TNM Finding v6. NCI Thesaurus. Code

C48234.

A finding about one or more characteristics of prostate cancer, following the rules of the TNM AJCC v6 classification system. 